\title{
Giant Cell Tumor Originating from the Anterior Arc of the Rib
}

\begin{abstract}
We report a case of giant cell tumor originating from the anterior arc of the rib. The tumor and the surrounding chest wall were completely resected, and the chest wall defect was covered with Marlex mesh. Giant cell tumor of the bone usually originates from the epiphysis of long bones. Even when the tumor occur in ribs, it usually occur in the posterior aspect. However, giant cell tumor should be included in the differential diagnosis of a tumor originating from the anterior arc of the ribs.
\end{abstract}

Key Words : Bone Neoplasms; Giant Cell Tumors; Ribs

\author{
Jae Seung Shin, In Sung Lee, Aeree Kim*, \\ Baek Hyun $\mathrm{Kim}^{\dagger}$ \\ Department of Thoracic and Cardiovascular Surgery, \\ Pathology ${ }^{*}$ and Diagnostic Radiology ${ }^{\dagger}$, Korea \\ University Medical College, Seoul, Korea \\ Received : 8 November 2001 \\ Accepted : 25 January 2002 \\ Address for correspondence \\ Jae Seung Shin, M.D. \\ Department of Thoracic and Cardiovascular Surgery, \\ Ansan Hospital, Korea University Medical Center, \\ 516 Gojan-dong, Ansan 425-020, Korea \\ Tel : +82-31-412-5060, Fax : +82-31-414-3249 \\ E-mail : jason@korea.ac.kr
}

\section{INTRODUCTION}

Giant cell tumor (GCT) is found most often in the ends of long bones and is essentially located in the epiphyseal or epiphyseal-equivalent portions of bone. The rib is a rare site for GCT with an incidence below one per cent (1). Even the cases involving ribs, most were located in the posterior arc, i.e., the head and tubercle of ribs $(2,3)$. In this paper, we report a case of GCT originating from the anterior arc of the rib.

\section{CASE REPORT}

A 40-yr-old man presented with a four-month history of a progressively growing mass in the right anterior chest wall. The mass was hard, fixed to the chest wall, and mildly tender. It measured $8 \times 5 \mathrm{~cm}$. The overlying skin was normal. He had no specific pulmonary symptoms. A chest roentgenogram demonstrated a large, ill-defined mass with increased density in the cartilaginous portion of the anterior arc of the right second rib, and the anterior costochondral junction area of the rib was destroyed. A lateral view showed that the mass mainly grew posteriorly (Fig. 1). Computed tomography demonstrated a large lobulated soft tissue mass originating from the right second rib. The mass showed heterogeneous contrast enhancement and contained small necrotic or cystic components of low density. The second rib near the costochondral junction showed a forked appearance. The mass was attached to the aorta and the superior vena cava (Fig. 2). A bone scan demonstrated a focally increased uptake of forked appearance at the anterior arc of the right second rib. The serum level of acid phosphatase was increased (11.4 IU/L). But the serum levels of calcium, phosphorus and alkaline phsphatase are in normal ranges, i.e., $9.4 \mathrm{mg} / \mathrm{dL}, 2.8 \mathrm{mg} / \mathrm{dL}, 94 \mathrm{IU} / \mathrm{L}$, respectively. And the levels of tumor marker including alpha-fetoprotein, carcinoembryonic antigen, CA19-9 and CA125 are also in normal ranges. The tumor was completely resected with the chest wall surrounding the tumor including the upper hemisternum. The mass was easily detached from the aorta and the superior vena cava, however, adhesive lung was resected with the tumor. The chest wall defect was covered with Marlex mesh. The resected chest wall showed a relatively well demarcated tumor with expansion into the surrounding soft tissue. The tumor was $8 \times 6.5 \times 6 \mathrm{~cm}$ in size. Hemorrhage, necrosis, and cyst formation with yellow capsule were noted in the cross section (Fig. 3). Histologically, the tumor was composed of round, oval or spindle-shaped stromal mononuclear cells and uniformly interspersed multinucleated giant cells (Fig. 4). The pathological diagnosis was a giant cell tumor of the right second rib.

For the detection of recurrence, the serum level of acid phosphatase and bone scan were observed. During the 11 months after surgery, the patient doing well without the evidence of recurrence.

\section{DISCUSSION}

Giant cell tumor (GCT) of bone is an unusual neoplasm, accounting for about $4-5 \%$ of all primary bone tumors. Malignant GCT can arise de novo or via transformation from benign 


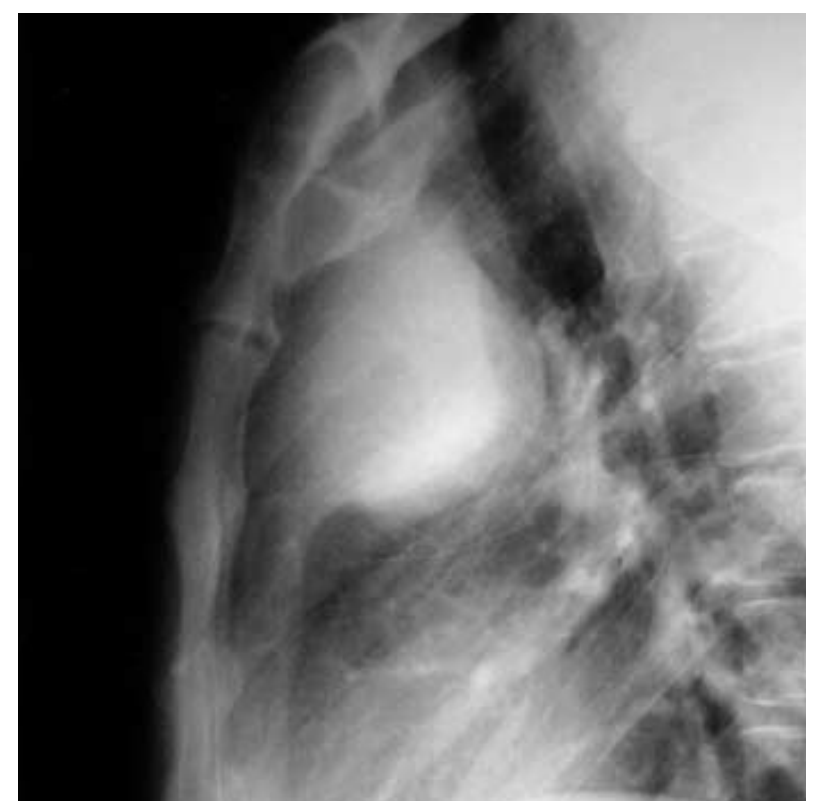

Fig. 1. A lateral view of the sternum demonstrates a large mass, which originated from the anterior chest wall and grew posteriorly.

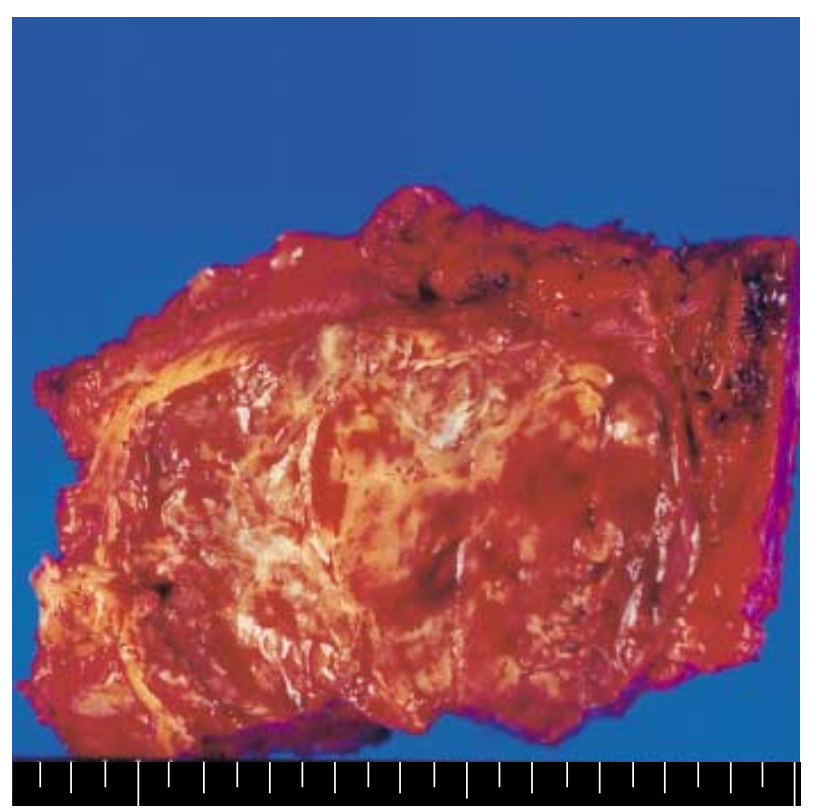

Fig. 3. A cross section of the tumor shows hemorrhage, necrosis, and cyst formation with yellow capsule.

neoplastic giant-cell lesion. The ends of long bone and epiphyseal portions of bone are the predilected sites for GCT. Individual cases have been reported in the scapula, sternum, ribs $(4,5)$. Gupta reviewed the literature on GCT, covered six series. According to him, 26 cases of GCT in the rib were reported out of 1,870 cases of bone GCT (6). Even in cases involving the ribs, most cases were located in the posterior arc of the ribs.

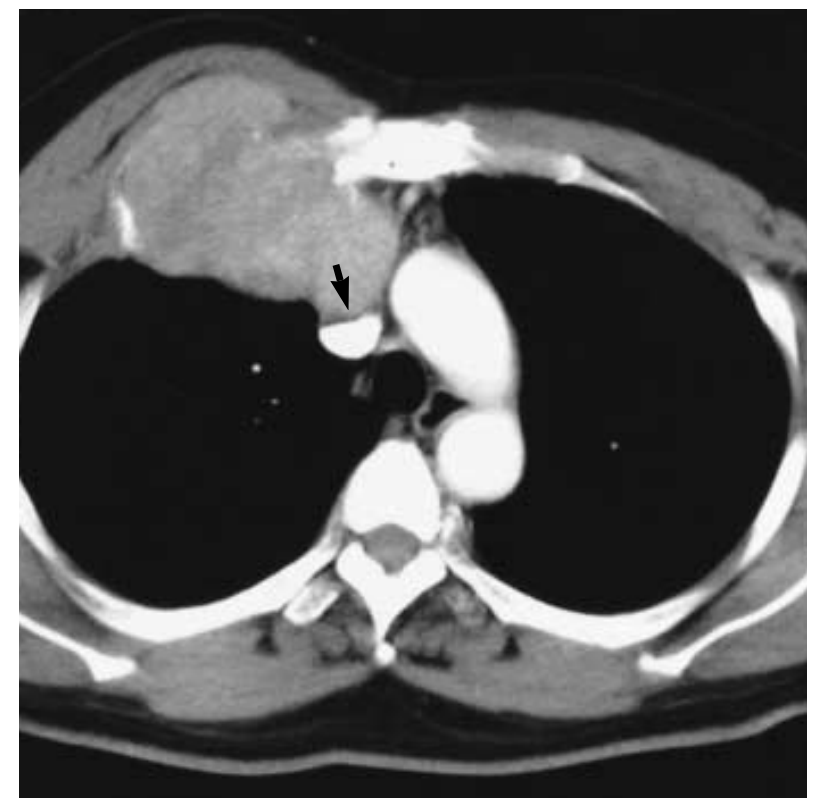

Fig. 2. Computed tomography demonstrates a large lobulated soft tissue mass originating from the right second rib and attached to the aorta and the superior vena cava (arrow).

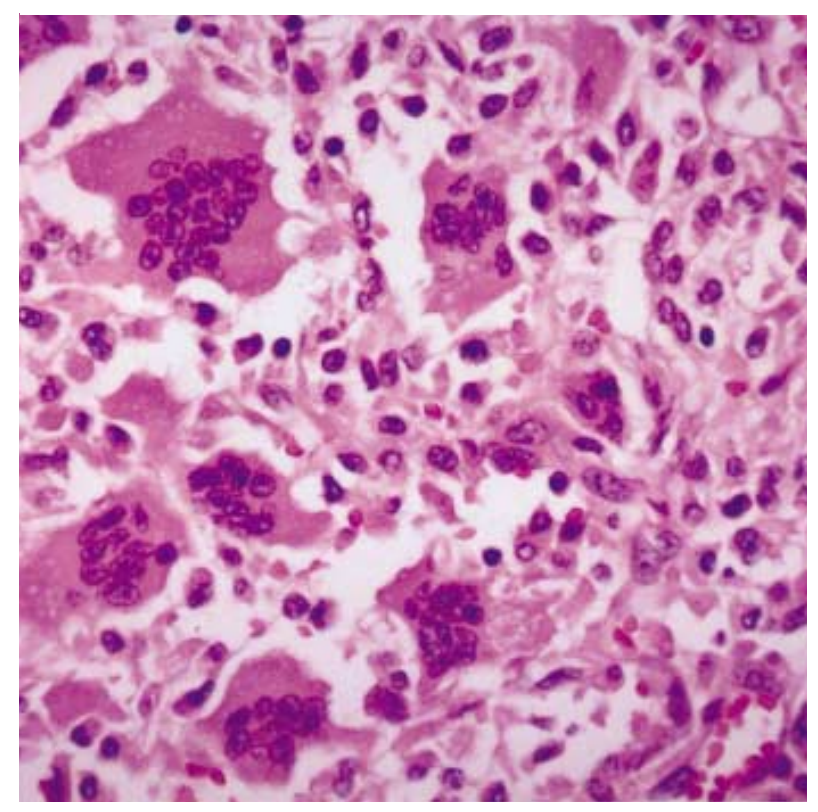

Fig. 4. Microscopically, the tumor shows oval, spindle shaped stromal mononuclear cells and uniformly interspersed multinucleated giant cells $(H \& E$ stain, $\times 100)$

Only a small number of cases were reported to originate from the anterior arc of the ribs $(6,7)$. Because of its rarity, GCT arising from the rib is difficult to diagnose, especially when the tumor is located in the anterior arc of the ribs. In our case, the initial impression of the musculoskeletal radiologist included plasmacytoma, lymphoma, chondrosarcoma, metastatic 
tumor, and malignant fibrous histiocytoma. GCT was not included in his differential diagnosis.

Serum acid phosphatase values are suggested to be a useful marker for diagnosis of GCT of the bone and for evaluation of the efficacy of treatment of the tumor. The values were high in $56 \%$ of GCT patients, and later decreased to normal values after resection (8). In our patient, the level of serum acid phosphatase was high (11.4 IU/L) before surgery, and fell into the normal range, i.e., $7.4 \mathrm{IU} / \mathrm{L}$ and $6.8 \mathrm{IU} / \mathrm{L}$ at the first month and eleventh month after surgery, respectively. The normal value of serum acid phosphatase as determined at our hospital is below $8 \mathrm{IU} / \mathrm{L}$.

Sometimes it is difficult to separate GCT from giant-cellrich osteosarcoma, malignant fibrous histiocytoma (MFH), chondroblastoma, aneurysmal bone cyst $(\mathrm{ABC})$ and brown tumor. Giant-cell-rich osteosarcoma and $\mathrm{MFH}$ are characterized by nuclear anaplasia and abnormal mitotic figures. And in the GCT, there is no neoplastic osteoid formation, which is the most pathognomonic finding of giant-cell-rich osteosarcoma. In chondroblastoma, chondroid matrix and plump, spindleshaped mononuclear cell component are present. Brown tumor has characteristic biochemical findings of hyperparathyroidism. GCT can be an underlying condition of secondary ABC. To make a diagnosis of $\mathrm{ABC}$, appropriate radiologic and clinical findings of $\mathrm{ABC}$ are mandatory. This case had only small areas of necrosis and cystic components.

Wide excision with chest wall reconstruction has been proven successful treatment of GCT originating from the rib. Radiation therapy is not recommended because most of the malignant transformations in GCT are associated with previous radiation therapy (9). Even in cases with pulmonary metastasis, aggressive surgical extirpation is recommended (10).

In summary, we described a rare case of GCT originating from the anterior arc of the rib. We suggest that GCT should be included in the differential diagnosis of a tumor originating from the anterior arc of the ribs, and aggressive surgical resection be the first choice for the treatment of this tumor.

\section{REFERENCES}

1. Hanna RM, Kyriakos M, Quinn SF. Case report 757: giant cell tumor of rib. Skeletal Radiol 1992; 21: 482-8.

2. Bonnet D, Barriere JR, Zimmermann JM, Eskandari J, Martet G, Robert JL, Lecamus JL, Barberet G, de Zuizon H. Giant cell tumors of the ribs. Apropos of a case. Rev Pneumol Clin 1992; 48: 79-85.

3. Tanaka F, Wada H, Mizuno H, Hitomi S. A case of giant cell tumor of the rib with magnetic resonance imaging. Eur J Cardiothorac Surg 1996; 10: 214-6.

4. Park YK, Ryu KN, Han CS, Kim YW, Yang MH. Giant cell tumor of the scapula associated with secondary aneurysmal bone cyst. J Korean Med Sci 1991; 6: 69-73.

5. Bay JO, Bignon YJ, Gros P, Jancovici R, Desangles F, Dubayle P, Hauteville D. Giant cell tumor of the sternum. Report of a case with a 17q isochromosome. Rev Rhum Engl Ed 1999; 66: 49-52.

6. Gupta V, Mittal R. Giant cell tumor of rib: rare location on the anterior aspect. Arch Orthop Trauma Surg 2000; 120: 231-2.

7. Brenner P, Warbanow FK, Krause-Bergmann A, Berger A. Rare differential diagnosis of breast tumor. Giant cell tumor of the ribs. Langenbecks Arch Chir 1997; 382: 64-8.

8. Goto T, Iijima T, Kawano H, Yamamoto A, Arai M, Matsuda K, Yokokura S. Serum acid phosphatase as a tumour marker in giant cell tumour of bone. Arch Orthop Trauma Surg 2001; 121: 411-3.

9. Dahlin DC. Giant cell tumor of bone: highlights of 407 cases. Am J Roentgenol 1985; 144: 955-60.

10. Takanami I, Takeuchi K, Naruke M, Kodaira S. Aggressive surgery for treating a pulmonary metastasis of a benign giant cell tumor of the bone: results in four cases. J Thorac Cardiovasc Surg 1998; 116: 649-51. 